\title{
Rheological characterization of coloured oil-in-water food emulsions with lutein and phycocyanin added to the oil and aqueous phases
}

\author{
Ana Paula Batista ${ }^{\mathrm{a}, *}$, Anabela Raymundo ${ }^{\mathrm{a}}$, Isabel Sousa ${ }^{\mathrm{b}}$, José Empis $^{\mathrm{c}}$

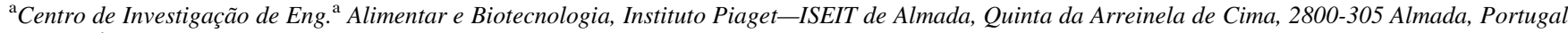 \\ ${ }^{\mathrm{b}}$ Secção de Ciência e Tecnologia dos Alimentos/DAIAT_Instituto Superior de Agronomia, Tapada da Ajuda, 1349-017 Lisboa, Portugal \\ ${ }^{\mathrm{c}}$ Centro de Eng ${ }^{\mathrm{a}}$ Biológica e Química-Instituto Superior Técnico, Av. Rovisco Pais, 1049-001 Lisboa, Portugal
}

Received 22 July 2004; accepted 22 February 2005

\begin{abstract}
The use of natural colourings in food products presents nutritional advantages, and certain pigments are associated with functional properties, e.g. antioxidant effects. This can be very advantageous in food products with high fat contents like mayonnaises. The aim of this work was to study the effect of adding natural pigments, lutein and phycocyanin, to the water and oil phases, respectively, of oil-in-water pea protein-stabilized emulsions, beyond the desirable and expected development of a green colour. The emulsions were prepared with $3 \%$ (w/w) pea protein, $65 \%(\mathrm{w} / \mathrm{w})$ vegetable oil, and varying concentrations of lutein and phycocyanin $(0.25-1.25 \% \mathrm{w} / \mathrm{w})$. Emulsions containing both pigments, in different proportions (total pigment concentration of $0.5 \%, \mathrm{w} / \mathrm{w}$ ) were also prepared. Oscillatory and steady-state measurements, as well as droplet size distribution and textural profile tests, were performed. The addition of lutein to the disperse oil phase promoted a decrease of the emulsions' rheological and textural parameters, while the addition of phycocyanin to the water (continuous) phase resulted in an increase of these properties. When using combinations of both pigments, an increase of the rheological and textural parameters with phycocyanin proportion was apparent, and a synergetic effect due to the presence of both pigments was found.
\end{abstract}

(C) 2005 Elsevier Ltd. All rights reserved.

Keywords: Emulsions; Lutein; Phycocianin; Rheology.

\section{Introduction}

Consumer's demand for more natural food products, presenting health benefits, has increased over the years. Besides the nutritional aspects, an appealing appearance with positive sensorial characteristics is also desired. As a result of this trend, the use of natural colourings in food products is preferred, while the synthetic colourings are perceived as undesirable and harmful and some are considered to be responsible for allergenic and intolerance reactions.

Many natural pigments currently used primarily for colouring purposes are phytochemicals, which have been

\footnotetext{
* Corresponding author. Tel.: +35121294 6269; fax: +35121294 1584.

E-mail addresses: pbatista@almada.ipiaget.org (A.P. Batista), araymundo@almada.ipiaget.org (A. Raymundo), isabelsousa@isa.utl.pt (I. Sousa), jempis@ist.utl.pt (J. Empis).
}

0268-005X/\$ - see front matter (C) 2005 Elsevier Ltd. All rights reserved. doi:10.1016/j.foodhyd.2005.02.009 associated to a nutraceutical effect (e.g. Guhr \& Lachance, 1998; Mazza, 1998; Pszczola, 1998), namely antioxidant activity (Downham \& Collins, 2000). Natural antioxidants are now thought to possibly prevent the incidence of many diseases such as cancers, cardiovascular and age related diseases, by protecting cells against oxidative damage.

Carotenoids are a main source of natural colourings, widely distributed in nature, and over 600 pigments with varied structures have been identified (Olson \& Krinsky, 1995). Carotenoids are terpenoid compounds with a long conjugated polyene chain, which determines the light absorption properties and consequently the colour (yellow to red) and phytochemical properties (Astorg, 1997). These compounds are biosynthesised by bacteria, algae, fungi and plants (Armstrong \& Hearst, 1996), but not by animals, who have to obtain them from their food (Astorg, 1997). Carotenoids have been used by the food industry to colour foods and beverages (e.g. orange juice) and are precursors of many important chemicals responsible for the flavour of foods and the fragrance of flowers (Gouveia \& Empis, 2003). 
Much scientific research has been completed on the health benefits of carotenoids that lie in two main areas: antioxidant and pro-vitamin A activity (e.g. from $\beta$ carotene). Several epidemiologic studies have demonstrated a correlation between increased carotenoid intake and reduced incidence of cardiovascular disease (Halliwell, 2000) and certain types of cancer, such as breast and lung cancer (De Stefani et al., 1999; Reddy, Odhav, \& Bhoola, 2003; Tavani, et al., 1999), atherosclerosis, cataracts, macular degeneration and other major degenerative diseases (Cooper, Eldridge, \& Peters, 1999) as well as an increased resistance to viral, bacterial, fungal and parasitic infection (Gouveia \& Empis, 2003).

Carotenoids can be classified in two types of compounds: carotenes, which are unsaturated hydrocarbons, e.g. licopene, $\alpha$ - and $\beta$-carotene; and xanthophylls, more abundant in nature, which present one or more functional groups containing oxygen, e.g. lutein, astaxanthin and cantaxanthin.

Lutein and zeaxhantin ( $3,3^{\prime}$-dihydroxy- $\alpha$-carotene) isomers (they differ by the position of one double bound) are xanthophylls, carotenoids with two hydroxyl groups in the conjugated polyene chain (Krinsky, Landrum, \& Bone, 2003).

Lutein, which is the most abundant of these two isomers, can be found in green leaf vegetables like broccoli and spinach and are commercially extracted from the Marigold Flower (Tagetes erecta) for the production of orange colourings for the food and beverages industry and production of dietary supplements. Epidemiological studies provide evidence to suggest that lutein may protect against Age-related Macular Degeneration (AMD), a leading cause of blindness in people over 65 (Mozzafarieh, Sacu, \& Wedrich, 2003; Pratt, 1999; Seddon et al., 1994). This is related to the fact that lutein and zeaxanthin are the only carotenoids quantitatively identified in the human macula (Bone, Landrum, Fernandez, \& Tarsis, 1998), and absorb the short wavelength light preventing damaging effects on the retina (Ham, 1983).

All carotenoid molecules present a hydrophobic character, and consequently have affinity to the disperse oil phase of the emulsion. Nevertheless, it should be considered that terminal hydroxyl groups of xantophylls, like lutein, can provide a certain polar character (Khachatryan, 2003) and potential interfacial activity, as well as the ability to bind with proteins through intermolecular hydrogen bonds (Bassi, Pineau, \& Marquardt, 1993; Moros, Darnoko, Cheryan, Perkins, \& Jerrel, 2002).

Another source of natural colourings are phycobiliproteins, which are water soluble fluorescent proteins derived from cyanobacteria and eukaryotic algae. In these organisms, they are used as accessory or antenna pigments for photosynthetic light collection. They absorb energy in portions of the visible spectrum $(450-650 \mathrm{~nm})$ that are poorly utilized by chlorophyll and, through fluorescence energy transfer, convey the energy to chlorophyll at the photosynthetic reaction center (Arad \& Yaron, 1992).

Phycobiliprotein structure includes linear tetrapyrrole chromophores (bilins) covalently linked via one or two tioether links to the cystein residues of apoproteins. In many algae the phycobiliproteins are arranged in subcellular structures called phycobilisomes, which allow the pigments to be arranged geometrically in a manner which helps to optimize the capture of light and transfer of energy (Arad \& Yaron, 1992; Borowitzka, 1989).

Phycocyanin is a blue phycobiliprotein (absorption maximum at $610-650 \mathrm{~nm}$ ), from Spirulina maxima (Arthrospira) widely used as a fluorescence marker in clinical diagnosis, and also as colouring in the pharmaceutical and cosmetics industry. Using phycocyanin as food colouring is not yet permitted within Europe or the USA but it is authorized in Japan, where it has been used in products like chewing gums, candies and dairy products (e.g. yoghurts) (Kawasaki \& Kaneko, 1978; Ogawa, Tezucha, Tsucha, Tanabe, \& Iwamoto, 1979; Shoten \& Kogyo, 1981). Antioxidant, anti-inflammatory, neuroprotective and hepatoprotective effects have been attributed to phycocyanin (Romay et al., 1998; Romay, Gonzalez, Ledon, Remirez, \& Rimbau 2003; Romay, Remirez, \& Gonzalez, 2001).

The use of these natural colourings in food systems is limited by the nature of the food matrix in which the pigment is to be dispersed and to the interactions with the other food components (proteins, polysaccharides, lipids, sugars, salts, etc.). In food emulsions, the addition of colouring pigments can affect the stability of the system according to their distribution between the oil, water, and interfacial regions and to specific interactions with the local environment, especially with emulsifier molecules. The molecules in an emulsion distribute themselves among these three regions according to their concentration and polarity (Wedzicha, 1988). The molecules that have significant amounts of both polar and non-polar groups tend to be surface active (Dalgleish, 1996; Damodaran, 1996; Dickinson, 1992), while polar molecules tend to be located primarily in the aqueous phase and non-polar molecules in the oil phase.

The constituents in a food emulsion interact with each other, either physically or chemically, to determine the overall physicochemical and organoleptic properties of the final product (Coupland \& McClements, 1996; Dickinson \& Stainsby, 1982; Landy, Courthaudon, Dubois, \& Voilley, 1996; Wedzicha, Zeb, \& Ahmed, 1991). The efficient production of high quality food emulsions therefore, depends on knowledge of the contribution that each individual constituent makes to the overall properties and how this contribution is influenced by the presence of the other constituents (McClements, 1999).

Oil-in-water food emulsions are often stabilized by proteins. Previous studies have showed that vegetable proteins from leguminous seeds, like lupin (Franco, Raymundo, Sousa, \& Gallegos, 1998; Raymundo, Franco, 
Gallegos, Empis, \& Sousa, 1998; Raymundo, Franco, Gallegos, \& Sousa, 2002; Raymundo, Franco, Partal, Sousa, \& Gallegos, 1999), pea (Bower, Gallegos, Mackley, \& Madiedo, 1999; Franco, Partal, Ruiz-Marquez, Conde, \& Gallegos, 2000; Tomoskozi, Lasztity, Haraszi, \& Baticz, 2001) and soy (Bogracheva et al., 1994; Eliazade, Bartholomai, \& Pilosof, 1996; Floury, Desrumaux, \& Legrand, 2002; Roesch \& Corredig, 2002) can be good emulsifiers. These proteins present some additional advantages such as no cholesterol, positive agricultural impact and expectable superior microbiological quality.

The aim of this work was to study the effect of adding natural pigments, phycocyanin and lutein, to the aqueous and oil phases, respectively, of pea protein-stabilized oilin-water emulsions. Linear viscoelasticity, flow behaviour, texture analysis and droplet size distribution of the emulsions were evaluated for various pigment concentrations. The evolution of the emulsions colour parameters (Lab) with pigment concentration and over time has been previously studied (Raymundo, Osório, Reis, Sousa, \& Empis, 2002).

\section{Materials and methods}

\subsection{Preparation of oil-in-water emulsions}

Oil-in-water emulsions were prepared with $65 \%(\mathrm{w} / \mathrm{w})$ vegetable oil, $32 \%(\mathrm{w} / \mathrm{w})$ deionised water and $3 \%(\mathrm{w} / \mathrm{w})$ pea protein isolate (Pisane HD, Cosucra, Belgium). The protein isolate was dispersed in the water under magnetic stirring (30 min, at room temperature) and emulsification was carried out at $13,000 \mathrm{rpm}, 5 \mathrm{~min}$ using an Ultra Turrax T-25 homogenizer (IKA, Germany), as reported previously by Franco, Raymundo et al. (1998). Lutein (FloraGLO ${ }^{\circledR} 20 \%$ liquid in safflower oil, Kemin Foods, USA) and phycocyanin protein, obtained from Arthrospira maxima (INETI-DER, Portugal) were dissolved in the aqueous and oil phases, respectively. Emulsions' containing various concentrations of lutein and phycocyanin $(0.25-1.25 \% \mathrm{w} / \mathrm{w})$ were prepared, as well as emulsions with mixtures of both pigments, in different proportions $(0.50 \% \mathrm{w} / \mathrm{w}$ total pigment $)$.

The emulsions were placed in cylindrical glass containers (60 mm diameter, $45 \mathrm{~mm}$ height), at $4{ }^{\circ} \mathrm{C}$ for $24 \mathrm{~h}$. All tests were performed at $20{ }^{\circ} \mathrm{C}$ and replicated at least three times.

\subsection{Rheological measurements}

The rheological measurements were performed in a controlled-stress rheometer (RS-75, Haake, Germany).

Oscillatory tests (mechanical spectra) were performed using a cone and plate sensor system $\left(35 \mathrm{~mm}\right.$ diameter, $2^{\circ}$ angle) in a frequency range of $0.001-100 \mathrm{~Hz}$, using stress values comprised in the linear viscoelastic region for each emulsion (4-20 Pa). The plateau modulus $\left(G_{N}^{0}\right)$ was the parameter used to compare emulsions. This figure can be considered as a measure of the intensity of the entangled network developed between the adsorbed and non-adsorbed protein molecules (Dickinson \& Hong, 1995). Hence, $G_{N}^{0}$ can be estimated as the value of $G^{\prime}$ for the minimum value of the loss tangent $\left(\tan \delta=G^{\prime \prime} / G^{\prime}\right)(\mathrm{Wu}, 1989)$

$G_{N}^{0}=\left[G^{\prime}\right]_{\tan \delta \rightarrow \text { minimum }}$

For steady-state flow measurements, a serrated parallel plate sensor system was used (20 $\mathrm{mm}$ diameter), in order to overcome the slip effect (Franco, Gallegos, \& Barnes, 1998). Viscosity versus shear stress curves were performed using a logarithmic ramp of stresses increasing in $30 \mathrm{~min}$ from 0.1 to $2000 \mathrm{~Pa}$. The comparison of the flow curves resulted from the adjustment of the Carreau model

$\eta=\frac{\eta_{0}}{\left[1+\left(\frac{\gamma^{\cdot}}{\gamma_{\mathrm{c}}}\right)^{2}\right]^{s}}$

where $\eta_{0}$ is the limiting viscosity for the first newtonian region, $\gamma_{c}$ is the critical shear rate for the onset of the shearthinning behavior and $s$ is a parameter related to the slope of this region.

Samples were covered with a layer of paraffin oil whilst on the rheometer, to prevent moisture loss.

\subsection{Texture profile analysis}

Texture profile analysis tests were performed in a texturometer TA-XT2 (Stable Micro System, UK). The samples, placed in cylindrical glasses $(60 \times 48 \mathrm{~mm})$, were punctured with a cylindrical probe of $38 \mathrm{~mm}$ diameter in a load cell of $5000 \mathrm{~g}$ ( $5 \mathrm{~mm}$ penetration, $2 \mathrm{~mm} / \mathrm{s}$ crosshead speed, $3 \mathrm{~s}$ waiting time). Firmness was considered as the height of the force peak during the first compression cycle of the force versus time, and was the parameter with better discriminating ability to compare emulsions.

\subsection{Droplet size distribution}

Droplet size distribution measurements were carried out in LASER light scattering equipment, the Malvern Mastersizer-X (Malvern, UK). Values of the Sauter mean diameter (Sprow, 1967), which is inversely proportional to the specific surface area of droplets, were obtained as follows

$d_{\mathrm{sv}}=\frac{\sum n_{i} d_{i}}{\sum n_{i} d_{i}}$

where $n_{i}$ is the number of droplets with a diameter $d_{i}$.

\subsection{Statistical analysis}

Statistical analysis, ANOVA/MANOVA, Post-Hoc Comparisons-Scheffé Test, was performed using 
the Software STATISTICA (Version 5.0, Statsoft, Inc., USA). The significance level was set at $95 \%$.

\section{Results and discussion}

\subsection{Lutein emulsions}

The linear viscoelastic behaviour (Fig. 1) shown by lutein emulsions, which presented orange tonalities, is typical of protein-stabilized emulsions in which an elastic network develops due to the occurrence of an extensive bridging flocculation process (Franco, Raymundo et al., 1998; Pal, 1995). The storage modulus $\left(G^{\prime}\right)$ was always higher than the loss modulus $\left(G^{\prime \prime}\right)$ in the frequency range studied, and the evolution of $G^{\prime}$ with frequency shows a tendency to the development of a plateau region, followed by a minimum in $G^{\prime \prime}$. The plateau modulus $\left(G_{N}^{0}\right)$ was studied as a characteristic parameter of this region. The viscoelastic properties of emulsions with lutein were significantly $(p<$ 0.05) lower than those evidenced by the control emulsion, i.e. without lutein addition (Fig. 1). However, there were no significant differences $(p<0.05)$ in the $G_{N}^{0}$ values of the emulsions with different contents of added lutein. This means that the addition of lutein destabilises the emulsions but this effect is independent of the pigment concentration, for the range tested.

The emulsions' steady-state flow curves (Fig. 2) presented a shear-thinning behaviour with a zero-shear rate limiting-viscosity $\left(\eta_{0}\right)$ at very low shear rates $\left(\gamma^{\circ}\right)$. The shear thinning region is a consequence of a dramatic shearinduced structural breakdown, related to a mechanism of oil droplet deflocculation, as previously reported for other concentrated food emulsions (Franco, Partal et al., 2000; Franco, Raymundo et al., 1998). The emulsion without lutein (control) presented $\eta_{0}$ values about 10 times higher than the lutein emulsions. A significant decrease in the Carreau equation $s$ parameter for the lutein emulsions

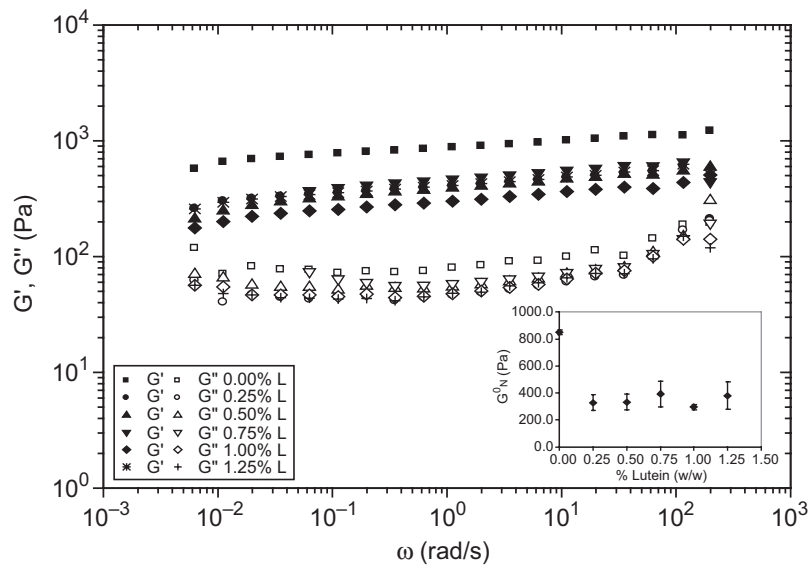

Fig. 1. Mechanical spectra for o/w emulsions with different lutein (L) concentrations, and respective plateau modulus $\left(G_{N}^{0}\right)$.

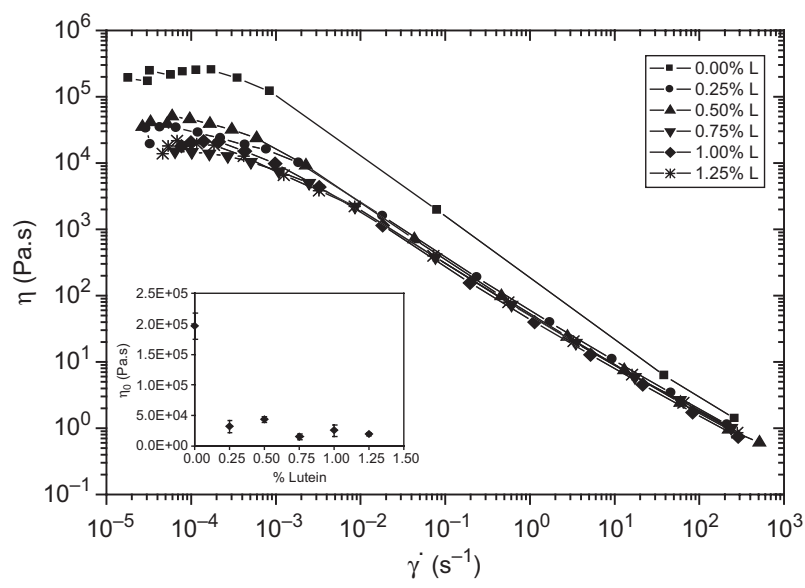

Fig. 2. Steady-state flow curves for o/w emulsions with different lutein (L) concentrations, and respective limiting viscosity $\left(\eta_{0}\right)$.

(0.38-0.40 $\left.\mathrm{Pa} \mathrm{s}^{2}\right)$ compared to the control $\left(0.47 \mathrm{~Pa} \mathrm{~s}^{2}\right)$ was also observed, which is in agreement with the viscous nature of these emulsions, since the $s$ parameter is a measure of the shear-thinning character of the material.

For all the texture parameters determined, a significant $(p<0.05)$ alteration with lutein addition was observed, while there were no differences between emulsions with varying lutein concentrations. Firmness decreased from $0.652 \mathrm{~N}$ down to $0.354-0.380 \mathrm{~N}$ (Fig. 3), adhesiveness from $1.225 \mathrm{~N} \mathrm{~s}$ down to $0.369-0.538 \mathrm{~N} \mathrm{~s}$, cohesiveness from 0.887 down to $0.729-0.753$, while springiness increased from 0.904 up to $0.959-0.971$.

Sauter mean diameter values suffered smaller variations due to the addition of lutein, but some differences were apparent between emulsions with different concentrations (Fig. 4).

Fats and oils influence the nutritional, organoleptic, and physicochemical properties of food emulsions in a variety of ways. The bulk physicochemical properties of edible fats and oils depend on the molecular structure and interactions of the triacylglicerol molecules they contain. The strength of

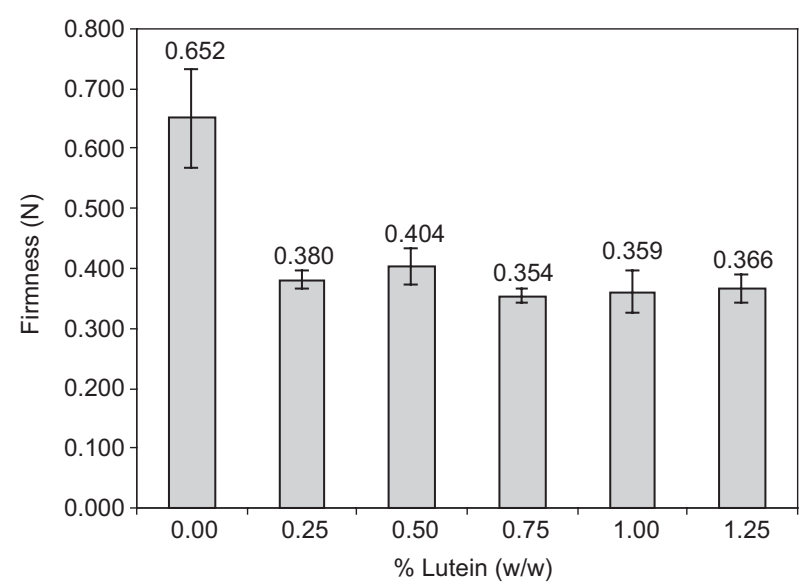

Fig. 3. Evolution of firmness for $\mathrm{o} / \mathrm{w}$ emulsions at different lutein concentrations. 


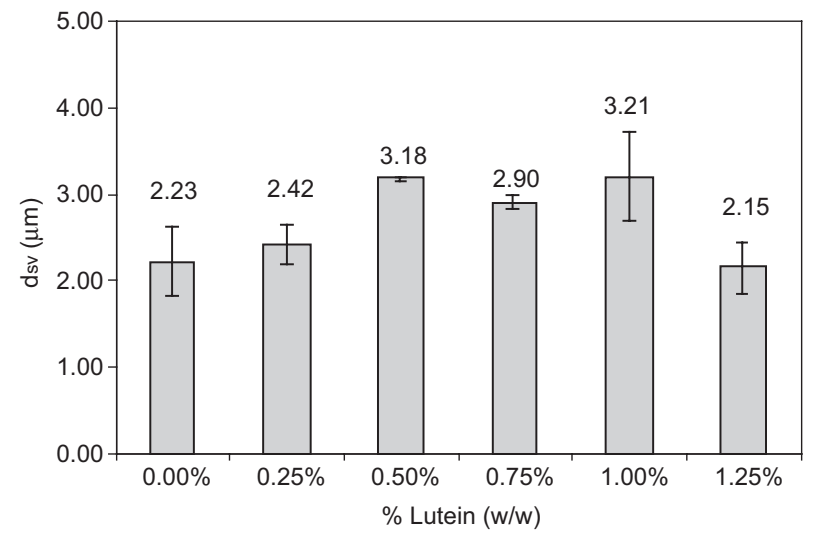

Fig. 4. Evolution of Sauter mean diameter $\left(d_{\mathrm{sv}}\right)$ for o/w emulsions at different Lutein concentrations.

the attractive interactions between molecules and the effectiveness of their packing in a condensed phase determines their melting point, boiling point, density and compressibility (McClements, 1999). Dissolving lutein in the oil fraction caused an important modification in the nature of the emulsions dispersed phase. Consequently, a reduction on the rheological and textural parameters occurred, as a result of emulsion destabilization.

Considering that lutein possesses two terminal hydroxyl groups, some interfacial activity might be expectable from its presence, indeed some competition with pea protein molecules for interface binding locations. However, at constant emulsifier (pea protein) concentration, only small variations on the droplet size distribution occurred with the addition of lutein, which indicates that the major role at the interface is played by pea protein, present at higher concentrations $(3 \%, \mathrm{w} / \mathrm{w})$ than lutein $(0.25-1.25 \%$ of a $20 \%$ oil suspension).

The interaction between proteins and lipid emulsifiers in mixed adsorbed layers at liquid and air-water interfaces have been widely studied in the last years (Bos \& Vliet, 2001; Patino, Nino, \& Sanchez, 2003; Wilde, Mackie, Husband, Gunning, \& Morris, 2004; Wilde, 2000). Although both proteins and lipid emulsifiers can stabilise foams and emulsions alone, their individual mechanisms of stabilisation are incompatible, often resulting in a dramatic destabilisation when both species are present at the interface-competitive destabilisation (Wilde, et al., 2004).

Although carotenoids are lipid molecules, they present significant structural differences from common used low molecular weight lipid emulsifiers, like mono- and diacylglycerols, and consequently should present different interfacial behaviour. In fact, terpenic compounds are not even considered as emulsifier (Garti, 1999).

However, a recent trend is to use lipid fractions (oleoresins) extracted from fruits, flowers, spices, leaves, etc. naturally rich in carotenoids (e.g. lycopene in tomato, or lutein in Marigold flower) to produce emulsions. These oleoresins consist of various triacylglycerols,

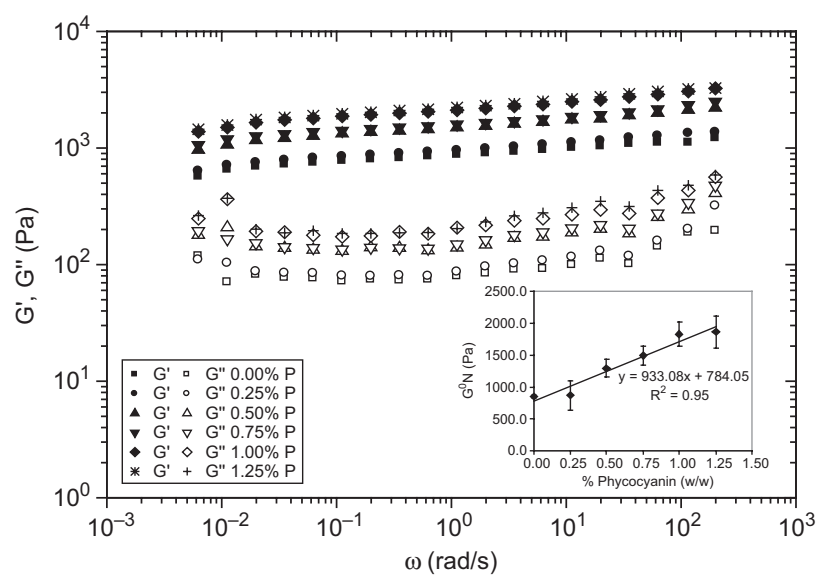

Fig. 5. Mechanical spectra for o/w emulsions at different phycocyanin (P) concentrations, and respective plateau modulus $\left(G_{N}^{0}\right)$.

non-saponifiable fatty components (e.g. waxes) and monoacylglycerol derivatives, and sometimes are 'self emulsifiable' and can form 'in situ' water-in-oil emulsions. These are called 'natural occurring self-emulsifying oils' for w/o emulsions, and can provide other functional properties due to the presence of carotenoids with potential antioxidant activity (Garti, 1999).

\subsection{Phycocyanin emulsions}

The addition of phycocyanin resulted in blue coloured oil-in-water emulsions with higher rheological and texture parameters, as is shown on Figs. 5-8.

In terms of linear viscoelastic behaviour it was observed that the plateau modulus $\left(G_{N}^{0}\right)$ increased linearly and significantly $(p<0.05)$ with phycocyanin concentration (Fig. 5).

A similar behaviour was observed in terms of steadystate flow curves (Fig. 6), with a significant $(p<0.05)$ linear increase of the $\eta_{0}$ values with phycocyanin content was

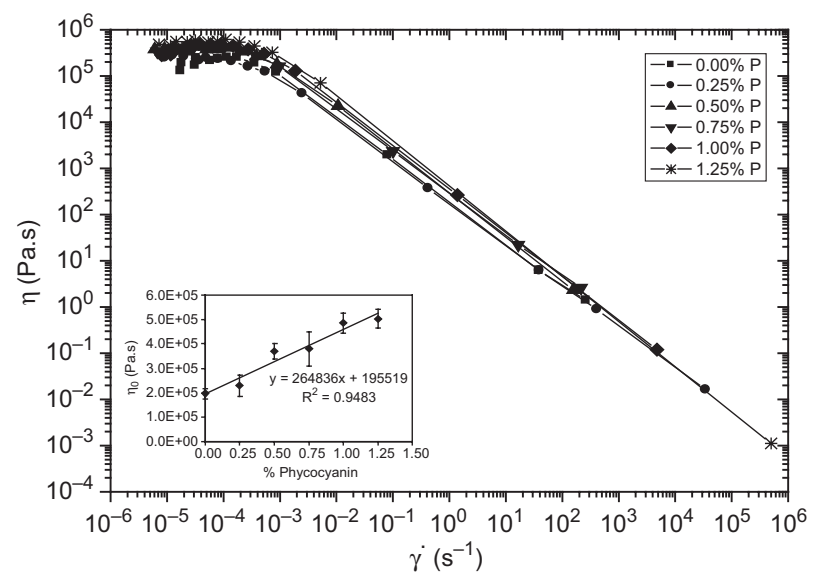

Fig. 6. Steady-state flow curves for o/w emulsions at different phycocyanin (P) concentrations, and respective limiting viscosity $\left(\eta_{0}\right)$. 


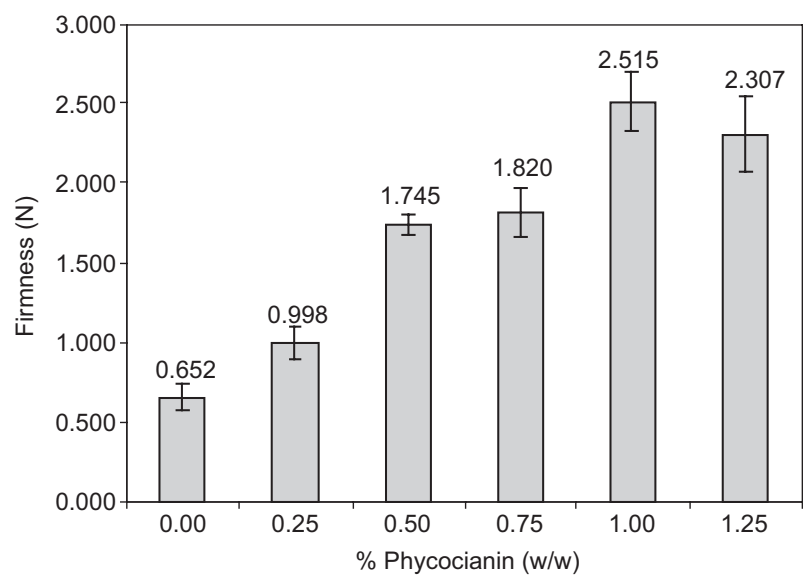

Fig. 7. Evolution of firmness for o/w emulsions with different phycocyanin concentrations.

observed, while for the $s$ and $\gamma_{\mathrm{c}}^{*}$ parameters of the Carreau equation, no significant differences were found.

As expected, the results from the textural tests are in agreement with the rheological measurements as can be observed from the firmness values (Fig. 7) which presented a significant $(p<0.05)$ linear $\left(R^{2}=0.9021\right)$ increase with pigment concentration. For the other texture parameters studied (adhesiveness, cohesiveness and springiness), no significant differences were found between the results of the emulsions at different phycocyanin concentrations.

In terms of droplet size distribution, a different behaviour was observed. For the control emulsion $(0.00 \%$, w/w phycocyanin) a Sauter mean diameter $\left(d_{\mathrm{sv}}\right)$ of $2.23 \mu \mathrm{m}$ was determined. The addition of phycocyanin promoted a significant $(p<0.05)$ increase on the $d_{\mathrm{sv}}$ values, except for the emulsion containing $0.75 \%(\mathrm{w} / \mathrm{w})$ pigment. Fig. 8 shows the evolution of $d_{\mathrm{sv}}$ values with phycocyanin concentration, which can be described by a polynomial equation $\left(R^{2}=0.9817\right)$ with a minimum for $0.75 \%(\mathrm{w} / \mathrm{w})$ pigment. Increasing the phycocyanin content from 0.25 up to $0.75 \%(\mathrm{w} / \mathrm{w})$ caused a reduction in $d_{\mathrm{sv}}$ values, while for

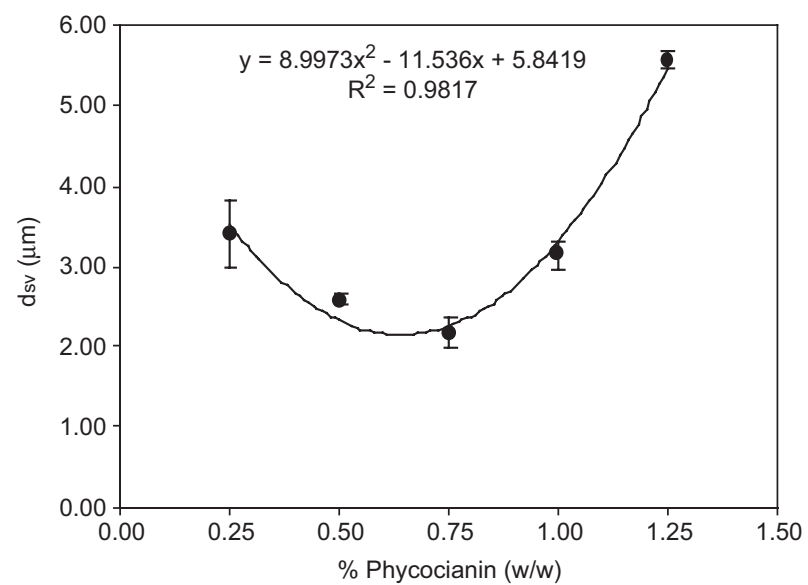

Fig. 8. Evolution of Sauter mean diameter $\left(d_{\text {sv }}\right)$ for o/w emulsions with different phycocyanin concentrations. higher phycocyanin levels (1.00-1.25\%, w/w) an increase on $d_{\text {sv }}$ values was observed.

Phycocyanin was added to the aqueous continuous phase of the emulsions but due to its amphiphylic nature, this pigment can lower the tension at the oil-water interface. In fact, previous studies have demonstrated that a protein isolate from blue-green algae (Spirulina platensis strain Pacifica) was capable of reducing the interfacial tension at the aqueous/air interface at relatively lower bulk concentrations compared to common food proteins. The surface active components were likely to be protein and/or proteinpigment complexes rather than individual protein molecules (Chronakis, Galatanu, Nylander, \& Lindman, 2000).

The presence of different types of proteins in oil-in-water emulsions might lead to a synergistic interaction, providing an improvement in the quality of the final product (Carrera, 2000; Clark, Wilde, Wilson, \& Wustneck, 1992) by reinforcing the protein layer. On the other hand, a decrease in the emulsion stability, due to the formation of weaker and more disordered mixed interfacial layers has also been reported (Imm \& Regenstein, 1999), due to thermodynamic incompatibility (Polyakov, Grinberg, \& Tolstoguzov, 1997) or to competitive adsorption of protein molecules at the interface (Dickinson, Rolfe, \& Dalgleish, 1990; Mine \& Keeratiurai, 2000). In fact, during and after emulsification, some of the individual protein components may be partially or wholly displaced from the interface by other more surface-active protein species or by small surfactant molecules (Dickinson, 1998). Hence, emulsion stability is strongly influenced by the dynamic aspects of protein competitive adsorption and by the nature of the interfacial protein interactions (Dickinson, 1998); and will be determined by the balance between these competitive and cooperative effects.

The addition of phycocyanin produced a decrease on the Sauter mean diameter of the emulsions, probably due to the formation of a disordered, mixed-protein layer. At increasing phycocyanin concentrations $(0.25-0.75 \% \mathrm{w} / \mathrm{w})$, the pigment either becomes more competitive with pea protein for the interface layer, or could instead be more involved in supramolecular entities with the pea protein, enhancing the local packing density at the adsorbed layer (Raymundo et al., 1999). As a result, the emulsions' structure was reinforced, yielding higher values for the rheological and textural parameters as well as smaller droplet diameters.

For higher phycocyanin concentrations (1.00-1.25\%) a drastic increase of the droplet size diameter occurred. This can be due to the competition mechanism referred to above. Phycocyanin proteins, in larger amounts, could have been substantially adsorbed at the oil-water interface during the emulsification process, faster than the pea protein molecules, and the latter become statistically unable to displace them. Accordingly, the rheological and textural parameters of the emulsions continued to increase with phycocyanin concentration. This should be related with an increase on the viscosity of the continuous phase due to the presence of 


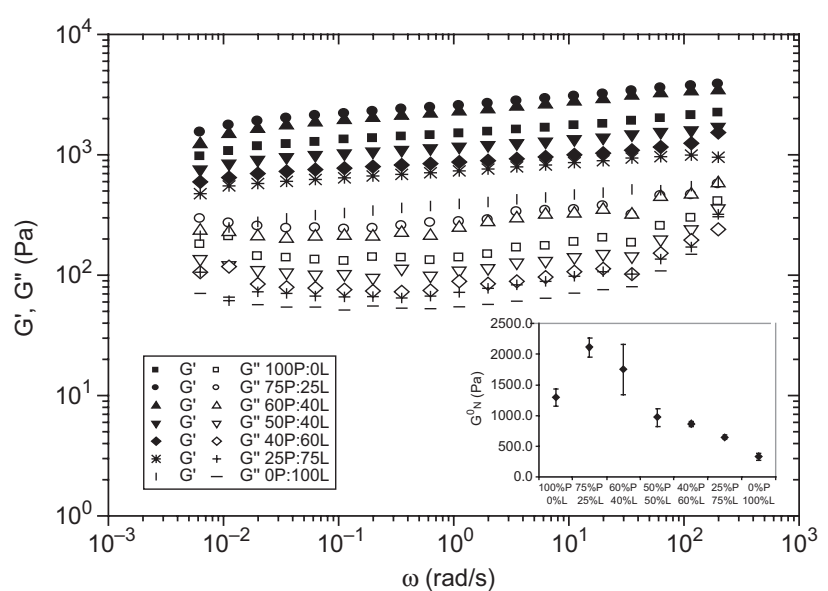

Fig. 9. Mechanical spectra for $\mathrm{o} / \mathrm{w}$ emulsions $\mathrm{T}$ different phycocyanin $(\mathrm{P})$ and lutein (L) proportions (total pigment concentration: $0.50 \%$, w/w) and respective plateau modulus $\left(G_{N}^{0}\right)$.

important amounts of unadsorbed proteins and to the formation of supramolecular entanglements among protein molecules adsorbed and non-adsorbed at the interface (Riscardo, Franco, \& Gallegos, 2003).

\subsection{Emulsions containing both pigments}

For the emulsions containing both pigments the rheological and textural parameters increased with the increment of the phycocyanin proportion relatively to the lutein. These emulsions presented a range of green tonalities.

From the mechanical spectra (Fig. 9) a significant ( $p<$ 0.05 ) increase on $G_{N}^{0}$ with phycocyanin proportion can be observed. However, it was also observed that the emulsions with higher phycocyanin and lower lutein concentrations (75P:25L and 60P:40L) presented higher $G_{N}^{0}$ values than the lutein-free emulsion (100P:0L). This fact evidences a surprising synergistic effect between both pigments, resulting in a better stabilisation of the emulsions.

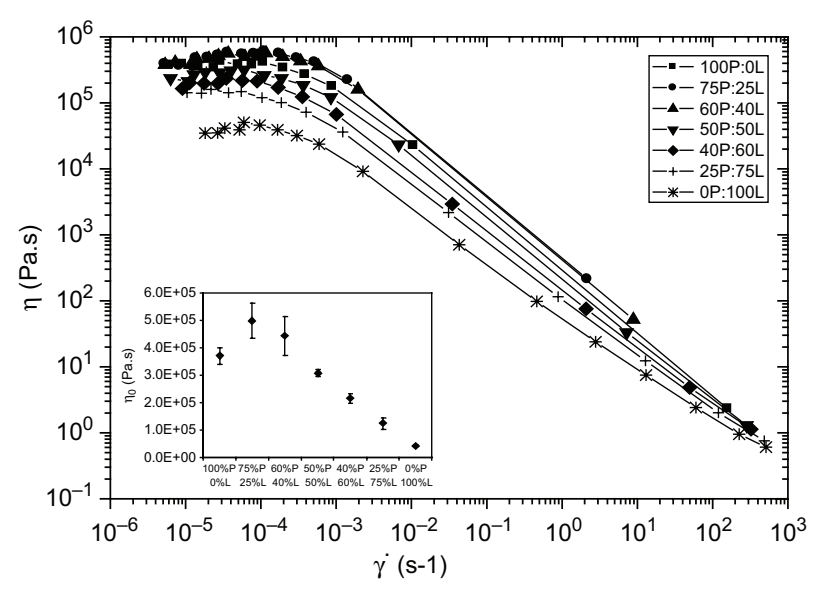

Fig. 10. Steady-state flow curves for $\mathrm{o} / \mathrm{w}$ emulsions at different phycocyanin $(\mathrm{P})$ and lutein $(\mathrm{L})$ proportions (total pigment concentrations: $0.50 \%, \mathrm{w} / \mathrm{w})$ and respective limiting viscosity $\left(\eta_{0}\right)$.

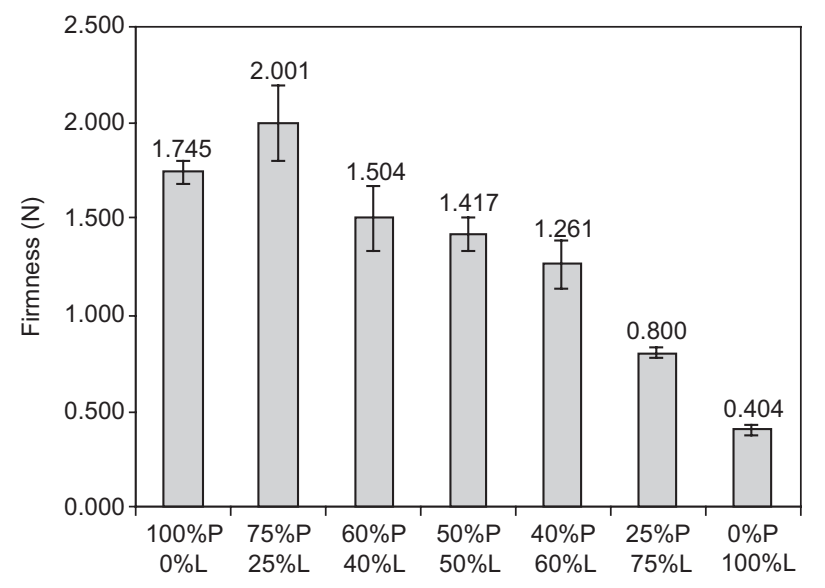

Fig. 11. Evolution of firmness results for $\mathrm{o} / \mathrm{w}$ emulsions at different phycocyanin $(\mathrm{P})$ and lutein $(\mathrm{L})$ proportions (total pigment concentration: $0.50 \%, w / w)$

The phycocyanin-free emulsion (0P:100L) presented a $G_{N}^{0}$ average value much smaller than the other emulsions.

These results were similar in terms of steady-state flow behaviour (Fig. 10), with the $\eta_{0}$ values increasing with phycocyanin proportion and yielding higher values for the mixtures with low lutein proportions (under 50\%) than for the lutein-free emulsion. This tendency was also observed for the $s$ parameter, which increased from 0.43 up to $0.48 \mathrm{~Pa} \mathrm{~s}^{2}$ with phycocyanin proportion (P25:L75 to $\mathrm{P} 75: \mathrm{L} 25)$, and presenting 0.40 and $0.46 \mathrm{~Pa} \mathrm{~s}^{2}$ for the luteinand phycocyanin-free emulsions, respectively.

Firmness results (Fig. 11) also increased with phycocyanin proportion. Although, no significant $(p<0.05)$ differences were found between the firmness values of the lutein-free emulsion and the 75P:25L and 60P:40L emulsions. This could be due to the smaller accuracy of the textural tests, when compared to rheological fundamental tests. For adhesiveness there were only significant differences $(p<0.05)$ between the 100P:0L $(2.228 \mathrm{Ns})$ and

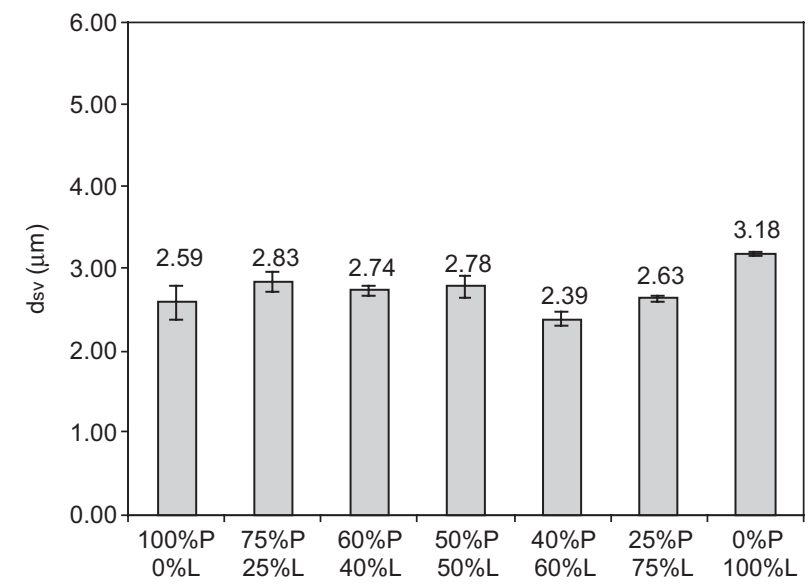

Fig. 12. Evolution of Sauter mean diameter $\left(d_{\mathrm{sv}}\right)$ for $\mathrm{o} / \mathrm{w}$ emulsions at different phycocyanin (P) and lutein (L) proportions (total pigment concentration: $0.50 \%, \mathrm{w} / \mathrm{w})$. 
0P:100L $(0.538 \mathrm{~N} \mathrm{~s})$. No significant differences $(p<0.05)$ were found between cohesiveness results and springiness decreased with phycocyanin proportion (Fig. 12).

In terms of droplet size distribution, the phycocyanin-free emulsion, which showed much lower values for the rheological and textural properties, presented significantly $(p<0.05)$ higher $d_{\mathrm{sv}}$ values, while the other emulsions presented similar, smaller $d_{\text {sv }}$ values. This fact evidences the important role that phycocyanin plays on stabilising $\mathrm{o} / \mathrm{w}$ emulsions.

\section{Conclusion}

The use of lutein and phycocyanin to colour food emulsions induced significant structural modifications in these colloidal systems. Lutein addition modified the nature of the oil phase originating emulsions with much smaller rheological and textural properties but with similar $d_{\text {sv }}$ results, comparing with the control emulsion ( $0.00 \%$ lutein). The addition of phycocyanin had a significant influence on the rheology of the continuous phase and through interactions with pea protein at the interfacial layer. As a result, the rheological and textural parameters increased linearly with phycocyanin concentration, while $d_{\mathrm{sv}}$ results presented a polynomial behaviour with a minimum for $0.75 \%(\mathrm{w} / \mathrm{w})$ pigment concentration. When using combinations of both pigments the rheological and textural characteristics of the emulsions increased with phycocyanin proportion while $d_{\mathrm{sv}}$ values remained similar. A synergistic effect was observed when using small amounts (under 50\% proportion) of lutein.

\section{Acknowledgements}

The authors thank PhD Alberto Reis (INETI-DER) for the phycocyanin production; Kemin Industries, Inc., and Cosucra Groupe Warcoing, for providing lutein and pea protein isolate samples, respectively, Dias de Sousa, S.A. for the use of Malvern Mastersizer equipment.

\section{References}

Arad, S. M., \& Yaron, A. (1992). Natural pigments from red microalgae for use in foods and cosmetics. Trends in Food Science and Technology, 3, 92-97.

Armstrong, G. A., \& Hearst, J. E. (1996). Genetics and molecular biology of carotenoid biosynthesis. Journal of the Federation of American Societies for Experimental Biology, 10, 403-412.

Astorg, P. (1997). Food carotenoids and cancer prevention: An overview of current research. Trends in Food Science and Technology, 8, 406-413.

Bassi, R., Pineau, B., Dainese, P., \& Marquardt, J. (1993). Carotenoidbinding proteins of photosystem II. European Journal of Biochemistry, 212, 297-303.

Bogracheva, T., Davydova, Y., Bespalova, N. Y., Kondrashina, M. G., Bezrukov, E. E., \& Tolstoguzov, V. B. (1994). A study of stability of $\mathrm{o} / \mathrm{w}$ emulsions stabilized by soybean and pea globulins. Nahrung, 2, 121-127.

Bone, R. A., Landrum, J. T., Fernandez, L., \& Tarsis, S. L. (1998). Analysis of the macular pigment by HPLC: Retina distribution and age study. Investigation Ophtalmology Visual Science, 29, 843-849.

Borowitzka, M. A. (1989). Vitamins and fine chemicals from micro-algae. In M. A. Borowitzka, \& L. J. Borowitzka (Eds.), Micro-algal biotechnology (pp. 153-196). Cambridge, UK: Cambridge University Press, 153-196.

Bos, M. A., \& Vliet, T. (2001). Interfacial rheology properties of adsorbed protein layers and surfactants: A review. Advances in Colloid and Interface Science, 91, 437-471.

Bower, C., Gallegos, C., Mackley, M. R., \& Madiedo, J. M. (1999). The rheological and microstructural characterization of the non-linear flow behaviour of concentrated oil-in-water emulsions. Rheologica Acta, 38, $145-159$.

Carrera, C. (2000). Estructura, estabilidad, morfologia y caracteristicas reológicas de películas de emulsionantes alimentarios (lipidos y proteinas) esparcidas sobre la interfase aire-agua. $\mathrm{PhD}$ Thesis. Seville: University of Seville.

Chronakis, I. S., Galatanu, A. N., Nylander, T., \& Lindman, B. (2000). The behaviour of protein preparations from blue-green algae (Spirulina platensis strain Pacifica) at the air/water interface. Colloids and Surfaces A: Physicochemical and Engineering Aspects, 173, 181-192.

Clark, D. C., Wilde, P. J., Wilson, D. R., \& Wustneck, R. (1992). The interaction of sucrose esters with $\beta$-lactoglobulin and $\alpha$-casein from bovine milk. Food Hydrocolloids, 6, 173-186.

Cooper, D. A., Eldridge, A. L., \& Peters, J. C. (1999). Dietary carotenoids and certain cancers, heart disease, and age-related macular degeneration: A review of recent research. Nutrition Review, 57, 201-214.

Coupland, J. N., \& McClements, D. J. (1996). Lipid oxidation in food emulsions. Trends in Food Science and Technology, 7, 83.

Dalgleish, D. G. (1996). Food emulsions. In J. Sjoblom, Emulsions and emulsion stability. New York: Marcel Dekker.

Damodaran, S. (1996). Amino acids, peptides and proteins. In O. R. Fennema (Ed.), Food chemistry (p. 321). New York: Marcel Dekker, 321.

De Stefani, E., Boffeta, P., Deneo-Pellegrini, H., Mendilaharsu, M., Carzoglio, J. C., Ronco, A., et al. (1999). Dietary antioxidants and lung cancer risk: A case-control study in Uruguay. Nutrition Cancer, 34, $100-110$.

Dickinson, E. (1992). Introduction to food colloids. Oxford: Oxford University Press.

Dickinson, E. (1998). Proteins at interfaces and in emulsions: Stability, rheology and interactions. Journal of Chemical Society, Faraday Transactions, 94(12), 1657-1669.

Dickinson, E., \& Hong, S. T. (1995). Influence of water soluble non-ionic emulsifier on the rheology of heat-set protein stabilized emulsions gels. Journal of Chemical Society, Faraday Transactions, 43, 25-60.

Dickinson, E., Rolfe, S. E., \& Dalgleish, D. G. (1990). Surface shear viscosimetry as a probe of protein-protein interactions in mixed milk protein films adsorbed a the oil-water interface. International Journal of Biological Macromolecules, 12, 189-194.

Dickinson, E., \& Stainsby, G. (1982). Colloids in foods. London: Applied Science Publishers.

Downham, A., \& Collins, P. (2000). Colouring our foods in the last and next millennium. International Journal of Food Science and Technology, 35, 5-22.

Eliazalde, B. E., Bartholomai, G. B., \& Pilosof, A. M. R. (1996). The effect of $\mathrm{pH}$ on the relationship between hydrophilic/lipophilic characteristics and emulsification properties of soy proteins. Lebensm Wissenschaften Technology, 29, 334-339.

Floury, J., Desrumaux, A., \& Legrand, J. (2002). Effect of ultra-highpressure homogenization on structure and on rheological properties of soy protein-stabilized emulsions. Journal of Food Science, 67(9), 3388-3395.

Franco, J., Raymundo, A., Sousa, I., \& Gallegos, C. (1998). Influence of processing variables on the rheological and textural properties of lupin 
protein-stabilized emulsions. Journal of Agricultural and Food Chemistry, 46, 3109-3115.

Franco, J. M., Gallegos, C., \& Barnes, H. A. (1998). On slip effects in steady-state flow measurements of oil-in-water food emulsions. Journal of Food Engineering, 36, 89-102.

Franco, J. M., Partal, P., Ruiz-Marquez, D., Conde, B., \& Gallegos, C. (2000). Influence of $\mathrm{pH}$ and protein thermal treatment on the rheology of pea protein-stabilized oil-in-water emulsions. Journal of American Oil Chemists' Society, 77, 972-983.

Garti, N. (1999). What can nature offer from an emulsifier point of view: Trends and progress? Colloids and Surfaces A, 152, 125-146.

Gouveia, L., \& Empis, J. (2003). Relative stabilities of microalgal carotenoids in microalgal extracts, biomass and fish feed: Effect of storage conditions. Innovative Food Science and Emerging Technologies, 4, 227-233.

Guhr, G., \& Lachance, P. (1998). Role of phytochemicals in chronic disease prevention In Nutraceuticals-designer foods III. Trambell, US: Food and Nutrition Press Inc. (pp. 311-365).

Halliwell, B. (2000). Lipid peroxidation, antioxidants and cardiovascular disease: How should we move forward? Cardiovascular Research, 47(3), 410-418.

Ham, W. T. (1983). Ocular hazards of light sources: Review of current knowledge. Journal of Occupational Medicine, 25, 101-103.

Imm, J. Y., \& Regenstein, J. M. (1997). Interaction of commercial dairy proteins and chicken breast myosin in an emulsion system. Journal of Food Science, 62, 967-975.

Kawasaki, M., \& Kaneko, T. (1978). Colouring of food. Japanese Patent $78,047,572$.

Khachatryan, A. (2003). Random centroid optimization of lutein-enriched oil in water emulsion at acidic $p H$. Master of Science Thesis. Department of Food Science, Graduate Faculty of the Louisiana State University and Agricultural and Mechanical College.

Krinsky, N., Landrum, J., \& Bone, R. (2003). Biologic mechanisms of the protective role of lutein and zeaxanthin in the eye. Annual Review Nutrition, 23, 171-201.

Landy, P., Courthaudon, J. L., Dubois, C., \& Voilley, A. (1996). Effect of interface on model food emulsions on the volatility of aroma compounds. Journal of Agricultural and Food Chemistry, 44, 526.

Mazza, G. (1998). Functional foods biochemical and processing aspects. Basel: Technomic Publishing Co., Inc., Lancaster.

McClements, D. J. (1999). Food Emulsions: Principles Practice and Techniques. Boca Raton: CRC Press.

Mine, Y., \& Keeratiurai, M. (2000). Selective displacement of caseinate proteins by hensegg yolk lipoproteins at oil-in-water interfaces. Colloids and Surfaces B, 18, 1-11.

Moros, E. E., Darnoko, D., Cheryan, M., Perkins, E. G., \& Jerrel, J. (2002). Analysis of xantophylls in corn by HPLC. Journal of Agricultural and Food Chemistry, 50, 5787-5790.

Mozaffarieh, M., Sacu, S., \& Wedrich, A. (2003). The role of carotenoids, lutein and zeaxanthin, in protecting against age-related macular degeneration: A review based on controversial evidence. Nutrition Journal, 2, 20-27.

Ogawa, K., Tezucha, S., Tsucha, Y., Tanabe, Y., Iwamoto, H. (1979). Phycocyanin as a chewing gum coloring agent. Japanese Patent $79,138,156$

Olson, J. A., \& Krinsky, N. I. (1995). The colourful fascinating world of carotenoids: Important biological modulators. Journal of the Federation of American Societies for Experimental Biology, 9, 1547-1550.

Pal, R. (1995). Oscillatory, creep and steady-state flow behaviour of xanthan-thickened oil-in-water emulsions. American Journal of Chemical Engineers Journal, 41, 783-795.

Patino, J. M. R., Nino, M. R. R., \& Sanchez, C. C. (2003). Proteinemulsifier interactions at the air-water interface. Current Opinion in Colloid and Interface Science, 8, 387-395.

Polyakov, V. I., Grinberg, V. Y., \& Tolstoguzov, V. B. (1997). Thermodynamic incompatibility of proteins. Food Hydrocolloids, 11, $171-180$.
Pratt, S. (1999). Dietary prevention of age-related macular degeneration. Journal of the American Optometric Association, 70, 39-47.

Pszczola, D. (1998). The ABC's of nutraceutical ingredients. Food Technology, 52, 30-37.

Raymundo, A., Franco, J., Gallegos, C., Empis, J., \& Sousa, I. (1998). Effect of thermal denaturation of lupin protein on its emulsifying properties. Nahrung, 42, 220-224.

Raymundo, A., Franco, J. M., Empis, J., \& Sousa, I. (2002). Optimization of the composition of low-fat oil-in-water emulsions stabilized by white lupin protein. Journal of the American Oil Chemists Society, 79, 783-790.

Raymundo, A., Franco, J. M., Partal, P., Sousa, I., \& Gallegos, C. (1999). Effect of the lupin protein/surfactant ratio on linear viscoelasticity properties of oil-in-water emulsions. Journal of Surfactants and Detergents-American Oil Chemists Society, 2(4), 545-551.

Raymundo, A., Osório, N., Reis, A., Sousa, I., \& Empis, J. (2002). Novel emulsions containing functional colourings in both phases. In J. Empis (Ed.), Functionalities of pigments in food-conference proceedings (pp. 189-193). Sociedade Portuguesa de Química Publ, 189-193.

Reddy, L., Odhav, B., \& Bhoola, K. D. (2003). Natural products for cancer prevention: A global perspective. Pharmacology and Therapeutics, 99(1), 1-13.

Riscardo, M. A., Franco, J. M., \& Gallegos, C. (2003). Influence of composition of emulsifier blends on the rheological properties of salad dressing-type emulsions. Food Science and Technology International, 9(1), 53-63.

Roesch, R. R., \& Corredig, M. (2002). Characterization of oil-in-water emulsions prepared with commercial soy protein concentrate. Journal of Food Science, 67(8), 2837-2842.

Romay, C. H., Armesto, J., Remirez, D., Gonzalez, R., Ledon, N., \& Garcia, I. (1998). Antioxidant and anti-inflammatory properties of Cphycocyanin from blue-green algae. Inflammation Research, 47, 36-41.

Romay, C. H., Gonzalez, R., Ledon, N., Remirez, D., \& Rimbau, V. (2003). Phycocyanin: A biliprotein with antioxidant, anti-inflammatory and neuroprotective effects. Current Protein and Peptide Science, 4(3), 207-216.

Romay, C. H., Remirez, D., \& Gonzalez, R. (2001). Actividad antioxidante de la ficocianina frente a radicales peroxilicos y la peroxidacion lipidica microsomal. Revista Cubana de Investigaciones Biomédicas, 20(1), $38-41$.

Seddon, J. M., Ajani, U. A., Sperduto, R. D., Hiller, R., Blair, N., Burton, T. C., et al. (1994). Dietary carotenoids, vitamins A, C and E, and advanced age-related macular degeneration. Journal of the American Medical Association, 272, 1413-1420.

Shoten, K.K.S., Kogyo, D.I.K. (1981). Method for food colouring. Japanese Patent 56,005,143.

Sprow, F. B. (1967). Distribution of drop sizes produced in turbulent liquid-liquid dispersion. Chemical Engineering Science, 22, 435-442.

Tavani, A., Gallus, S., La Vecchia, C., Negri, E., Montella, M., Dal Maso, L., et al. (1999). Risk factors for breast cancer in women under 40 years. European Journal of Cancer, 35, 1361-1367.

Tomoskozi, S., Lasztity, R., Haraszi, R., \& Baticz, O. (2001). Isolation and study of the functional properties of pea proteins. Nahrung Food, 45(6), 399-401.

Wedzicha, B. L. (1988). Distribution of low-molecular weight food additives in dispersed systems. In E. Dickinson, \& G. Stainsby (Eds.), Advances in food emulsions. London: Elsevier (Chapter 10).

Wedzicha, B. L., Zeb, A., \& Ahmed, S. (1991). Reactivity of food preservatives in dispersed systems. In E. Dickinson (Ed.), Food polymers, gels and colloids (p. 180). Cambridge: Royal Society of Chemistry, 180.

Wilde, P., Mackie, A., Husband, F., Gunning, P., \& Morris, V. (2004). Proteins and emulsifiers at liquid interfaces. Advances in Colloid and Interface Science, 108/109, 63-71.

Wilde, P. J. (2000). Interfaces: Their role in foam and emulsion behaviour. Current Opinion in Colloid and Interface Science, 5, 176-181.

Wu, S. (1989). Chain structure and entanglement. Journal of Polymer Science, 27, 723-741. 